\title{
FENOMEN TAJEMNICY WCIELENIA W PISMACH DOGMATYCZNYCH ŚW. AMBROŻEGO
}

Tajemnica wcielenia Syna Bożego zajmuje poczesne miejsce w pismach dogmatycznych ${ }^{1}$ św. Ambrożego, zwłaszcza w specjalnie temu zagadnieniu poświęconym niewielkim traktacie De incarnationis dominicae sacramento, będącym odpowiedzią na wysuwane na ten temat wątpliwości $\operatorname{arian}^{2}$. Nie sposób jednak w krótkim opracowaniu wyczerpać całego bogactwa tego zagadnienia, dlatego skoncentrujemy się tutaj tylko nad niektórymi aspektami nauczania Biskupa Mediolanu, podkreślającymi fenomen tajemnicy wcielenia, a będą to kolejno: przyjęcie ciała przez Syna Bożego, czyli drugą Osobę Trójcy Świętej, podwójne zrodzenie Jezusa Chrystusa - jako Syna Bożego i jako syna Dziewicy Maryi, oraz tożsamość osobowa Syna Bożego z Jezusem Chrystusem.

1. „Nie Ojciec stał się ciałem, ale Słowo”3. Święty Ambroży, polemizując $\mathrm{z}$ arianami podkreślał, że Jezus Chrystus jest prawdziwym Bogiem. Negacja bóstwa Jezusa Chrystusa prowadziłaby, jego zdaniem, do przypisania wcielenia Bogu Ojcu, co czynili monarchianie (modaliści), zwani też patrypasjana$\mathrm{mi}^{4}$. Biskup Mediolanu przeciwstawia się zdecydowanie takim poglądom

${ }^{1}$ Wśród dzieł dogmatycznych św. Ambrożego uwzględniono: De fide ad Gratianum, De Spiritu Sancto, De incarnationis dominicae sacramento, Explanatio symboli ad initiandos, De mysteriis, De sacramentis i De poenitentia.

${ }^{2}$ Por. Paulinus Mediolanensis, Vita Ambrosii 18, PL 14, 33, tłum. J. Wojtczak (Życiorys św. Ambrożego napisany przez jego notariusza Paulina, w: Sw. Ambroży z Mediolanu, $O$ wierze lDo cesarza Gracjana/, tłum. I. Bogaszewicz, Warszawa 1970), 232.

${ }^{3}$ De fide III 2, 13, SAEMO 15, 198: „non enim Pater caro factus est, sed Verbum”, thum. I. Bogaszewicz, O wierze [Do cesarza Gracjana], Warszawa 1970, 83.

${ }^{4}$ Herezja ta, propagowana m.in. przez Prakseasza i Noeta ze Smyrny, głosiła tak doskonałą jedność Boga, że znosiła odrębność osób Bożych. W konsekwencji utożsamiono Ojca i Syna, i twierdzono, że to właśnie Ojciec stał się człowiekiem i cierpiał na krzyżu (pater passus est). Tę błędną naukę szerzył również Sabeliusz w III wieku dokonując pewnych modyfikacji. Według jego koncepcji bóstwo, które jest jedną monadą, objawia się na trzy różne sposoby: jako Ojciec w Starym Testamencie, jako Syn Boży we wcieleniu, a jako Duch Święty w wydarzeniu Pięćdziesiątnicy. 
twierdząc, że wcieliła się tylko druga Osoba Trójcy Świętej. Interesujący nas temat porusza w kontekście sporów z arianami, dowodząc, że Chrystus jest zarazem Bogiem i człowiekiem:

„Chrystus jako «Najwyższy» daje, jako człowiek prosi: co innego przysługuje Mu jako Stwórcy, a co innego jako człowiekowi. Jakkolwiek są to dary różne, to jednak pochodzą od jednego Sprawcy; przystało bowiem, aby nas Ten odkupił, który nas stworzył. Kto więc zaprzeczy, że Najwyższy oznacza Chrystusa? Kto bowiem myśli inaczej, ten tajemnicę wcielenia przypisze Ojcu"s.

Nasz autor zwracając się do arian konstatuje, że słowo „Bóg” należy również odnosić do Syna, w przeciwnym razie „niegodziwością Sabeliusza zdawać się będą przyjmować wcielenie Ojca"6. Przypomina, że istnieją takie teksty w Piśmie Świętym, których bez tego założenia nie można zrozumieć. Na dowód tego przytacza słowa z listu św. Pawła do Kolosan: „W nim też powstaliście przez wiarę $\mathrm{w}$ potęgę Boga, który go wskrzesił. I was, gdy byliście umarli w grzechach i w obrzezku ciała waszego, wespół z nim ożywił, darowawszy wam wszystkie grzechy, niszcząc cyrograf dekretu przeciw nam, który był nam przeciwny, i ten usunął, przybijając go do krzyża, wyzuwszy się z ciała" (Kol 2, 12-14) ${ }^{7}$. Na ich podstawie udowadnia, stosując dedukcyjny sposób myślenia, że ten, który „wskrzesił”, „ożywił”, „darował grzechy”, ,zniszczył cyrograf”, „przybił go do krzyża”, równocześnie „wyzuł się z ciała”. Nie może chodzić tutaj o działanie Ojca, bo to Słowo stało się ciałem ${ }^{8}$, więc kategorycznie stwierdza, że „nie kto inny «wyzuł się z ciała», tylko Syn Boży, który przyjął ciało" ${ }^{9}$. W Kościele mediolańskim IV wieku problem ten musiał być wciąż jeszcze aktualny, skoro sam Ambroży zaznacza, że często był przedmiotem jego pouczeń ${ }^{10}$. Przyczynę niewłaściwej interpretacji Pisma Świętego odnośnie tej kwestii upatruje w fakcie błędnego interpretowania tekstów odnoszących

Więcej na ten temat zob. m.in. M. Simonetti, Sabelio e il sabellianismo, ,Studi Storico-Religiosi” 4 (1980) 7-28; M. Slusser, The Scope of Patripassianism, „Studia Patristica” 17(1982) 169-175; J. Kelly, Poczqtki doktryny chrześcijańskiej, thum. J. Mrukówna, Warszawa 1988, 97-99.

5 De fide III 2, 8-9, SAEMO 15, 196, Bogaszewicz s. 82.

6 Tamże III 2, 12, SAEMO 15, 196, Bogaszewicz s. 82. Takie sformułowanie Ambrożego, świadczy o tym, ze modalizm w wydaniu Sabeliusza odczytywano również jako przypisanie wcielenia Bogu Ojcu, mimo iż według L. Padovese, koncepcja ta uniknęła mówienia o wcieleniu i cierpieniu Boga Ojca, por. Wprowadzenie do teologii patrystycznej, thum. A. Baron, Kraków 1994, 64.

7 Ambroży cytuje teksty Pisma Świętego według istniejących wówczas wersji łacińskich, szczególnie według tzw. Vetus Itala, ponieważ nie istniała jeszcze wersja Wulgaty Hieronima, por. Św. Ambroży, $O$ wierze, dz. cyt., 9, przypis 1. W niniejszym artykule fragmenty biblijne cytowane są za Ambrożym.

8 Por. De fide III 2, 13, SAEMO 15, 198: „,non enim Pater caro factus est, sed Verbum”.

9 Tamże III 2, 14, SAEMO 15, 198, Bogaszewicz s. 83.

${ }^{10}$ Por. Explanatio symboli 3, SAEMO 17, 28-30: „Deinde frequenter admonui, quia dominus noster Iesus Christus, filius Dei, solus carnem istam suscepit". 
się do Bóstwa i człowieczeństwa Chrystusa ${ }^{11}$. Sam swobodnie porusza się na tym gruncie ${ }^{12}$ i jest przekonany, że nauka Ariusza zwraca się przeciw samym jej wyznawcom, ponieważ negując wcielenie Syna Bożego, równocześnie nie potrafią wyjaśnić kwestii przyjęcia ciała przez Ojca ${ }^{13}$, co zgodnie z ich rozumowaniem byłoby logicznym następstwem.

Biskup Mediolanu dostrzega także dalsze następstwa tej błędnej nauki. Wyjaśniając formułę chrzcielną, stosowaną w Kościele mediolańskim w IV wieku, stwierdza: „Zrobiłeś tylko jedno zastrzeżenie. Wierzysz mianowicie, że na krzyżu zawisnął tylko Pan Jezus"14. Słowa te, mimo że zostały wypowiedziane w kontekście sporów z arianami, mają również wydźwięk antypatrypasjanistyczny ${ }^{15}$. Głoszenie doskonałej jedności Boga, znoszącej odrębność osób Bożych w jednym Bogu, konsekwentnie prowadziło do twierdzenia, że na krzyżu cierpiał Ojciec, skoro Syn nie jest inny od Ojca. Bardzo wyraźnie stwierdza to Ambroży mówiąc: „Widzicie więc, że arianie, oddzielając Syna od Ojca, wpadają w niebezpieczeństwo głoszenia męki Ojca"16. Nasz autor informuje wprost, że wyznawcy takich poglądów byli określani mianem patry$\operatorname{pasjan}^{17}$. Ich twierdzenia o cierpieniu Ojca spowodowały, że ortodoksyjni wyznawcy chcąc zapobiec błędnym poglądom uważali, iż należy Boga Ojca określać jako invisibilis (niewidzialny) i impassibilis (niecierpiętliwy). Biskup Mediolanu w tym kontekście precyzuje, że terminy te odnoszą się generalnie do natury Bożej, którą posiada również Syn Boży ${ }^{18}$. Jako Bóg jest On niewidzialny i niecierpiętliwy, a cierpieniom podległy jest tylko w przyjętym ciele, gdyż natura Boża jako doskonała nie może być poddana cierpieniu. Ambroży stwierdza, że, co prawda, te określenia pomogły w zachowaniu czystej i nieska-

${ }^{11}$ Por. De fide V 8, 115, SAEMO 15, 390: „Pia mens, quae leguntur, secundum carnem divinitatemque distinguit, sacrilega confudit et ad divinitatis detorquet iniuriiam, quidquid secundum humilitatem carnis est dictum".

${ }^{12}$ Teksty Pisma św. Starego i Nowego Testamentu są bazą i celem jego wiary i nauczania, por. L. Herrmann, Ambrosius von Mailand als Trinitätstheologe, ZKG 69 (1958) 199.

${ }^{13}$ Por. De fide V 8, 115, SAEMO 15, 390: „Ego excusationem habeo de filio «hominis», ille de Patre non habet, quia Pater non suscepit carnem".

${ }^{14}$ De mysteriis 5, 28, SAEMO 17, 150, POK 26, 42.

15 Zdaniem H. Pietrasa, to stwierdzenie $\mathrm{z}$ formuły chrzcielnej wydaje się być pewnym anachronizmem, gdyż monarchianie (patrypasjanie) byli aktywni przede wszystkim w III wieku, por. H. Pietras, By nie milczeć o Bogu. Zarys teologii Ojców Kościoła, Kraków 1991, 187; tenże, Początki teologii Kościoła, Kraków 2000, 59. Wydaje się jednak, że pewne idee wciąż pozostawały żywe i powracały na wokandę sporów dogmatycznych, skoro św. Ambroży nie tylko że nawiązuje do nich, ale nawet imiennie wzmiankuje o tych błędnych poglądach: jeden raz wprost mówi o patrypasjanach, por. Explanatio symboli 4; częściej natomiast wymienia Sabeliusza i sabelian, por. De fide I 1, 6; I 8, 57; II 9, 80; II 10, 86; III 2, 12; V 8, 104; V 8, 105; De incarnationis 2, 8; De Spiritu Sancto II 12, 142; III 16, 117; Explanatio symboli 4.

16 De fide III 2, 13, SAEMO 15, 198, Bogaszewicz s. 83.

17 Por. Explanatio symboli 4, SAEMO 17, 30: ,patripassiani cum emerissent”.

18 Por. Explanatio symboli 4, SAEMO 17, 30. 
żonej wiary, dodaje jednak z przykrością, że i arianie posługują się nimi, czynią to jednak przewrotnie w tym celu, aby w porównaniu z Ojcem ,,pokazać, że Syn jest widzialny i cierpiętliwy"19. Dlatego też jest wyraźnie przeciwny używaniu tych sformułowań, bo są pomocne w szerzeniu arianizmu ${ }^{20}$. Nasz autor w swoim nauczaniu podkreśla z całą mocą, że Jezus Chrystus w naturze Bożej jest niecierpiętliwy: „Dlaczego Bóstwu przypisujesz utrapienia ciała i ludzki ból wiążesz z naturą Boską?" "21. Bóg nie posiada ciała, jest bezcielesny ${ }^{22}$. Dlatego więc nie można przypisać cierpień Bogu Ojcu. Tylko Syn Boży - odwieczna Moc Boża ${ }^{23}$ i Mądrość Boża ${ }^{24}$, przyjęła ciało; cierpiał jednak nie w naturze Boskiej, lecz ludzkiej.

2. „Bez ojca, bez matki, bez rodowodu” (Hbr 7, 3) ${ }^{25}$. Święty Ambroży precyzuje także naukę o pochodzeniu Jezusa Chrystusa. W tym celu powołuje się na na List do Hebrajczyków, w którym Melchizedek, król Szalemu, został nazwany tym, który jest „bez ojca, bez matki, bez rodowodu” (Hbr 7, 3). Te określenia, zdaniem autora De fide odnoszą się w pełni również do Jezusa Chrystusa, ,który jako człowiek narodził się bez ojca, a jako Bóg bez matki i który nie ma rodowodu, gdyż napisane jest: «Rodzaj jego kto wypowie»"? (Iz $53,8)^{26}$. Biskup Mediolanu wyodrębnia więc tutaj dwie różne rzeczywistości: zrodzenie Boże i zrodzenie ludzkie. Jezus Chrystus w swej boskiej naturze nie ma matki, ponieważ ,nie jest ani uczyniony, ani stworzony, ale zrodzony z Ojca, a żadne stworzenie nie było świadkiem tego zrodzenia"27. Jako człowiek natomiast nie ma ojca, ponieważ poczęcie ludzkie Jezusa różniło się w swej genezie od poczęcia innych ludzi. Określenie ,sine patre secundum incarnationem natus est" ${ }^{28}$ wskazuje, że jest to poczęcie bez aktu płciowego, które związane jest $\mathrm{z}$ wielką tajemnicą mocy Bożej. Autorem tego cudownego dzieła jest Duch Święty ${ }^{29}$. Ta prawda zostanie mocno wyakcentowana zwłaszcza

19 Tamż 4, SAEMO 17, 30, POK 26, 27.

${ }^{20}$ Por. tamże 4, SAEMO 17, 30: „ubi fides integra est, sufficiunt praecepta Apostolorum, cautiones, licet sacerdotum, non requirantur".

21 De incarnationis 5, 41, SAEMO 16, 402-404, POK 26, 118.

22 Por. tamże 3, 20, SAEMO 16, 386: „incorporeus est deus”.

23 Por. De Spiritu Sancto III 5, 33, SAEMO 16, 280: „quia tegimentum corporis «virtus Dei sempiterna» suscepit".

${ }^{24}$ Por. De incarnationis 5, 41, SAEMO 16, 403-404: „, sapientia [...] amictu carnis circumdaretur".

${ }^{25}$ De fide III 11, 88, SAEMO 15, 234: „, sine patre et sine matre et sine generatione”, Bogaszewicz s. 103.

26 Tamże.

27 Tamże III 14, 113-114, SAEMO 15, 244, Bogaszewicz s. 109.

28 Tamże III 14, 113-114, SAEMO 15, 244.

${ }^{29}$ Por. De Spiritu Sancto, II 5, 38, SAEMO 16, 188: „Opus ergo Spiritus partus est, opus Spiritus fructus est ventris”, por. tamże III 22, 168: „qui natus est de Spiritu Sancto ex Maria virgine". 
w homiliach dla katechumenów, gdzie Ambroży wprost powie, że Jezus Chrystus ,nie narodził się z męskiego nasienia, lecz z Ducha Świętego i z Dziewicy Maryi, z dziewiczego łona" "30. Nadprzyrodzony sposób poczęcia Jezusa Chrystusa dostrzec można także w samym określeniu „Dziewica”, jakie Ambroży często używa w odniesieniu do Maryi. Tytuł ten implikuje nadprzyrodzoność poczęcia i narodzenia Jezusa Chrystusa. Wskazuje na to następujący fragment:

„Znajdzie się w Nim zresztą wiele cech zarówno zgodnych z naturą (ludzką), jak i ją przekraczających. (...) To zaś, że poczęła Go i porodziła Dziewica, wychodziło poza warunki naturalne i zmierzało do przekonania nas, że Ten, który podejmuje odnowę natury, jest Bogiem i jednocześnie człowiekiem, bo narodził się z człowieka zgodnie z naturą" ${ }^{31}$.

Dziewica poczęła bez udziału mężczyzny i po zrodzeniu pozostała dziewicą ${ }^{32}$. Zatem jest to wyraz ingerencji Bożej, fenomen przekraczający naturę. Z dalszego tekstu wynika, że Jezus Chrystus, zrodzony z Dziewicy, jest równocześnie Bogiem i człowiekiem, który „nie niszczy ani nie wypiera się ciała, ale daje mu rękojmię eschatologicznego odnowienia" 33 .

Mediolańczyk, mówiąc o narodzeniu Chrystusa z Dziewicy, równocześnie akcentuje boskość Jezusa Chrystusa. Te dwie rzeczywistości są nierozdzielne, zawsze idą ze sobą w parze. Dla naszego autora jest to sprawa priorytetowa, ponieważ rozumie, że chcąc poznać całą prawdę o Chrystusie trzeba wierzyć, że jest On zarazem prawdziwym jednorodzonym Synem Bożym, jak też prawdziwym człowiekiem, zrodzonym z Dziewicy ${ }^{34}$. Nauczając o zrodzeniu z Ojca i z Dziewicy, używa zamiennie różnych form gramatycznych pochodzących od czasowników: nascor, gigno i genero. Nie oznacza to jednak, że tak samo rozumie proces zrodzenia z Boga Ojca i zrodzenia z Dziewicy. Sam zresztą wyjaśnia, że są to dwie odrębne rzeczywistości. Zrodzenie z Ojca wskazuje na naturę boską Jezusa Chrystusa - Syna Bożego, na Jego odwieczność, natomiast zrodzenie z Dziewicy oznacza ludzką naturę Chrystusa, która została stworzona i tym samym zaistniała w czasie ${ }^{35}$. Można więc mówić o Synu Bo-

${ }^{30}$ De sacramentis IV 3, 12, SAEMO 17, 90-92, POK 26, 74, por. także De poenitentia I 3, 13, SAEMO 17, 180: ,non enim sicut omnes homines ex viri erat et feminae permixtione generatus, sed natus de Spiritu Sancto et virgine inmaculatum corpus susceperat".

31 De incarnationis 6, 54, SAEMO 16, 414, POK 26, 122.

32 Biskup Mediolanu przyjmuje więc dziewictwo Maryi ,in partu” i ,post partum”.

33 Padovese, dz. cyt., 113.

${ }^{34}$ Por. De fide V 2, 37, SAEMO 15, 352: „quia non est perfecta cognitio, nisi quae et secundum aeternitatem unigenitum Deum verum Dei filium Iesum Christum et secundum carnem generatum ex virgine confitetur". Stwierdzenie perfecta cognitio wskazuje, że prawdziwą wiarę głosi Kościół, reprezentowany przez biskupa Ambrożego, ponieważ w nim wyznaje się prawdę, ze Jezus Chrystus jest jednorodzonym Synem Bożym i synem Dziewicy Maryi.

${ }^{35}$ Por. De fide I 16, 102, SAEMO 15, 108: „Si autem distat inter creatum et genitum, ut ego arbitror, cum legerimus genitum, non utique idem et genitum intellegimus et creatum". 
żym: zrodzony i stworzony, ale tylko w odniesieniu do Jego dwóch natur odwiecznej Boskiej i przyjętej ludzkiej ${ }^{36}$. Ambroży ukazuje tym samym, że doktryna arian, przeciwko której występuje, jest błędna. Chrystus jest prawdziwym Bogiem, zrodzonym z Ojca „przed wiekami”37, równym Jemu pod każdym względem, a nie jednym z mniejszych bóstw (mocy), bo takie rozumienie, zdaniem Ambrożego, byłoby równoznaczne z powrotem do wielobóstwa ${ }^{38}$.

Równocześnie jest Chrystus prawdziwym człowiekiem, zrodzonym z Dziewicy, Synem Bożym, który przyjął ludzkie ciało. Na potwierdzenie tego nasz Autor w traktacie De fide przytacza tekst proroka Izajasza $(9,6)$ : „Maluczki narodził się nam, Syn jest nam dany", wyjaśniając, że Syn w swojej naturze Boskiej nie mógł się dla nas narodzić, ponieważ narodził się przed nami i jest Stwórcą całego stworzenia ${ }^{39}$. Nie można też na podstawie tych słów wyciągać wniosku, że Syn Boży miał początek swojego istnienia, ponieważ On ,istniał zawsze i «był na początku»" 40 . Jak więc można by zinterpretować ten cytat biblijny? Dla Ambrożego sprawa jest jasna. Syn Boży rodzi się dla nas tym, czym nie był, a więc przybiera naturę ludzką: puer ex virgine, corpus ex Maria ${ }^{41}$. I konkluduje: „tym bowiem jest po nas, tamtym przed nami” ${ }^{42}$; ,po nas”, bo jest uczestnikiem natury ludzkiej, „przed nami”, ponieważ posiada naturę boską.

Nasz autor wielokrotnie odwołuje się też do pochodzenia Chrystusa z rodu Dawida. Czyni to przytaczając fragmenty biblijne zarówno ze Starego jak i Nowego Testamentu. Z jednej strony przywołuje je w celu udowodnienia bóstwa Jezusa Chrystusa, a $z$ drugiej jako argumenty potwierdzające ludzką naturę Chrystusa. Koronnym tekstem wskazującym na bóstwo Chrystusa jest dla niego fragment Ewangelii wg św. Mateusza, opisujący spotkanie Chrystusa z faryzeuszami, podczas którego rozprawia On na temat psalmu 110 i zadaje im kłopotliwe pytanie: „Jeśli więc Dawid w duchu nazywa go [Mesjasza - przyp. J.F.] Panem, to jakże jest synem jego?” (Mt 22, 45). Ambroży interpretując powyższy tekst wyjaśnia, że termin Pan odnosi się do Boga i oznacza zwierzchność, powagę władzy. „Panem króla Dawida może być tylko Bóg”“33. Jedno-

${ }^{36}$ Por. tamże I 16, 102, SAEMO 15, 108: „Dicant igitur generatum ex Patre, ex virgine procreatum, aut dicant, quomodo Dei filius et genitus et creatus. Una natura, et maxime Dei, diversitatem non recipit".

37 Tamże I 1, 6, SAEMO 15, 54-56, Bogaszewicz s. 10.

38 Por. tamze I 1, 6, SAEMO 15, 54-56: „neque ut Arrius plures credendo et dissimiles potestates plures deos gentili errore faciamus, quia scriptum est «Audi Istrahel, dominus deus tuus dominus unus est”".

${ }^{39}$ Por. tamże III 8, 55, SAEMO 15, 218 : „Neque enim nobis natus est, qui et ante nos natus est et totius est conditor creaturae".

40 Tamże III 8, 55, SAEMO 15, 218, Bogaszewicz s. 94.

41 Tamże III 8, 55, SAEMO 15, 218.

42 Tamże III 8, 55, SAEMO 15, 218, Bogaszewicz s. 94.

43 Tamże V 8, 104, SAEMO 15, 382-384, Bogaszewicz s. 185. 
znacznie odczytuje, że chodzi tutaj o relację synostwa ${ }^{44}$. Dlatego Mesjasz, nazwany Panem w sensie natury boskiej, nie może być synem Dawida, który był tylko człowiekiem, bo Dawid w Duchu nazywając Mesjasza Panem, stwierdza, że jest On Bogiem ${ }^{45}$.

Druga grupa tekstów, przywołujących postać Dawida, wskazuje na przynależność Jezusa Chrystusa do rodzaju ludzkiego. Są to bezpośrednie świadectwa Pisma św. (por. np. Mt 20, 30 $0^{46} ; \mathrm{Rz} 1,3^{47} ; 2$ Tm 2, $8^{48}$ ), które stwierdzają wprost pochodzenie Jezusa $z$ rodu Dawida i świadczą, że sam Chrystus nie zaprzecza takiemu pochodzeniu ${ }^{49}$. Ambroży akcentuje więc ludzką proweniencję Jezusa i wykazuje, że Jezus Chrystus nie jest osobą wyimaginowaną, ale naprawdę zaistniał w konkretnym czasie. Nadto w Jego osobie wypełniają się wszystkie proroctwa, które od wieków kierował Bóg do narodu izraelskiego. Zastanawiające jest jednak, dlaczego Ambroży tak często podkreśla pochodzenie Jezusa z rodu Dawida, mimo że prawda ta została dość szeroko naświetlona, zarówno w Starym, jak i w Nowym Testamencie, uwydatniając równocześnie boskość Jezusa Chrystusa. W kontekście różnorodnych sporów doktrynalnych, dotyczących osoby Jezusa Chrystusa, które toczyły się w owym czasie, lub których echo wciąż jeszcze brzmiało, wydaje się uzasadnionym tak mocne akcentowanie tych rzeczywistości przez Ambrożego. Z jednej bowiem strony odmawiano Chrystusowi prawdziwości natury boskiej, a z drugiej nie wierzono w realność Jego człowieczeństwa. Dlatego też dla naszego autora wyjaśnienie tych prawd było sprawą najwyższej rangi ${ }^{50}$. Wspaniale ukazuje to w kontekście ewangelicznej sceny z dwoma uzdrowionymi przez Jezusa ślepcami, gdzie ze słów jego komentarza przebija wielkie zaangażowanie dla tej sprawy, a nawet wręcz ogromna pasja:

„[Jezus Chrystus - przyp. J.F.] jest bowiem Synem Bożym wbrew Ebionowi, synem Dawida wbrew manichejczykom, Synem Bożym wbrew Fotynowi, synem Dawida wbrew Marcjonowi; jest Synem Bożym wbrew Pawłowi z Samosaty, synem Dawida wbrew Walentynowi, a Synem Bożym wbrew Ariuszowi i Sabeliuszowi, spadkobiercom błędów pogańskich; jest synem Dawida wbrew Żydom, którzy patrząc na Wcielonego Syna Bożego w swym bezbożnym szaleństwie uważali Go wyłącznie za człowieka" 51 .

${ }^{44}$ Por. tamże V 8, 100, SAEMO 15, 380-382: „Itaque dominatum non esse, ubi vera progenies est”.

${ }^{45}$ Por. tamze V 8, 101, SAEMO 15, 382: „O quam caute propter Hemiarrianos etiam in hoc testimonio Dominus fidei prospexit".

${ }^{46}$ Por. tamże V 8, 104, SAEMO 15, 382-384.

${ }^{47}$ Por. tamże III 4, 34, SAEMO 15, 270.

${ }^{48}$ Por. De incarnationis 6, 53, SAEMO 16, 414.

${ }^{49}$ Por. De fide V 8, 104, SAEMO 15, 382-384: „,non enim negat esse se «David filium secundum carnem»".

${ }^{50}$ Por. Herrmann, art. cyt., 211: „Wahre Gottheit und wahre Menschheit, das ist der Tenor der ambrosianischen Christologie".

${ }^{51}$ De fide V 8, 105, SAEMO 15, 384, Bogaszewicz s. 186. 
W tej wypowiedzi Ambroży przedstawił niemal cały katalog różnorodnych herezji, i na zasadzie powtórzonych kilkakrotnie antytez ukazał, że Jezus Chrystus jest zarazem Synem Bożym i synem Dawida, a zatem jest prawdziwym Bogiem i prawdziwym człowiekiem.

3. „Ten sam się wcielił, który był przed wiekami" 52 . W nauczaniu Ambrożego, mimo że związane ono było przede wszystkim z problemami epoki, w której żył i tworzył, można już wyraźnie dostrzec pewne zagadnienia, które w przyszłości staną się przedmiotem kontrowersji chrystologicznych. Do takich kwestii należy niewątpliwie problematyka podmiotowej jedności Jezusa Chrystusa w Jego podwójnym: boskim i ludzkim sposobie istnienia. Podobna jest więc do tej, którą zajmowały się sobory powszechne w Efezie (431) i Chalcedonie (451). Nie ma wprawdzie u naszego autora tak wyrazistych sformułowań, jakie zostały użyte przez Ojców soborowych, ale trzeba brać pod uwagę fakt, że sobory te zwołano już w innej epoce, jeden 34 , a drugi 54 lata po jego śmierci, co dla ówczesnej, rozwijającej się szybko chrystologii, jest dość dużym fragmentem czasu. Przyjrzyjmy się więc bliżej kilku wypowiedziom Doktora z Mediolanu, w celu lepszego poznania jego nauki na ten temat.

Najpierw w traktacie De fide przywołuje ewangeliczną scenę, w której Jan Chrzciciel, widząc nadchodzącego Chrystusa wypowiada o nim słowa: „Oto Baranek Boży”, a następnie dodaje: „Ten ci jest, o którym powiedziałem: „Przychodzi po mnie mąż, który stał się przede mną, bo pierwej był niż ja" ${ }^{33}$. Zdaniem Ambrożego, w tym wyrażeniu odczytać można tajemnicę wcielenia i wiekuistość bóstwa. O pierwszej rzeczywistości świadczy przede wszystkim słowo „mąż”, który „stał się”. Bóg nie może stać się, bo istnieje zawsze. Słowo „mąż" oznacza więc człowieka, który staje się poprzez konkretne zaistnienie w czasie. Dalszy natomiast człon zdania (,,bo pierwej był niż ja”) wskazuje na bóstwo, które również odnosi się do owego męża, wskazanego przez Jana Chrzciciela, a zatem Ambroży może powiedzieć, że „Ten sam się wcielił, który był przed wiekami, byśmy nie sądzili, że jest dwóch synów" ${ }^{54}$. W dobie powstawania licznych herezji chrystologicznych, ,okaleczających” Jezusa Chrystusa, zarówno z Bóstwa, jak i z człowieczeństwa, to zdanie jest mocnym argumentem za jednością Jego osoby, łączącej dwie natury boską i ludzką. Nie ma dwóch synów, jednego, który był przed wiekami, a więc uczestnika natury boskiej, i drugiego, który zaistniał w czasie jako człowiek. „Być przed wiekami” to przywilej natury Bożej, wcielić się to przybrać naturę ludzką. Ambroży wyraźnie wskazuje, że te dwie rzeczywistości zapodmiotowane są w jednej Osobie Jezusa Chrystusa.

52 Tamże III 10, 67, SAEMO 15, 224-226: ,ipsum incarnatum [...] qui ante saecula erat”, Bogaszewicz s. 98.

53 Tamże.

54 Tamże. 
Jeszcze obszerniej i wyraźniej wyjaśnia tę prawdę na innym miejscu:

„Ale zgodnie z nauką Kościoła jeden i ten sam jest Synem Boga Ojca i Dawida, gdyż tajemnica Wcielonego Boga jest zbawieniem dla wszelkiego stworzenia według słów Pisma: «By bez Boga zakosztował śmierci za wszystkich» (Hbr 2, 9); innymi słowy, całe stworzenie bez jakiegokolwiek cierpienia ze strony bóstwa miało zostać odkupione ceną krwi Pańskiej, jak to w innym miejscu mówi Pismo: «Wszelkie stworzenie zostanie oswobodzone z niewoli skażenia» $(\mathrm{Rz} 8,21){ }^{55}$.

Mediolańczyk potwierdza więc jednoznacznie tożsamość Syna Bożego z synem Dawida. Zaznacza też, że nie jest to tylko jego stanowisko, ale prawdziwa nauka Kościoła. Warto zauważyć, że Ambroży stosuje tutaj argument soteriologiczny uzasadniając, że fakt wcielenia był konieczny dla całego stworzenia w celu zbawienia. Wcielony Bóg oswobodził całe stworzenie od niewoli skażenia, jak zresztą zapisał św. Paweł w liście do Rzymian ( $R z 8,21)$. Wyraźnie podkreśla jednak, że ze strony bóstwa nie było jakiegokolwiek cierpienia (sine passione aliqua), zgodnie ze słowami Pisma św.: „By bez Boga zakosztował cierpienia za wszystkich" (Hbr 2, 9). Powodem więc zjednoczenia bóstwa z człowieczeństwem w Jezusie Chrystusie jest odkupienie człowieka.

Wyjaśniając dalej jedność osoby Jezusa Chrystusa w dwóch naturach pisze:

\begin{abstract}
„Dlatego też słów Pisma «ukrzyżowali Pana chwały» $(1$ Kor 2,8$)$ nie należy tak rozumieć, jakoby Go ukrzyżowali w Jego chwale, ale że Ten sam jest Bogiem i Ten sam człowiekiem, Bogiem z racji bóstwa, człowiekiem zaś z racji przyjętego ciała. Jezus Chrystus, Pan chwały, został ukrzyżowany w tym znaczeniu, że mając dwie natury, Boską i ludzką, wycierpiał mękę w naturze ludzkiej, tak że jednocześnie i Panem chwały jest Ten, który cierpiał i - jak mówi Pismo - «Synem Człowieczym, który zstąpił z nieba» $(\mathrm{J} 3,13){ }^{n 6}$.
\end{abstract}

Wyklucza więc możliwość cierpienia Boga, bo tak inaczej można określić „Pana chwały”. Natomiast ze słów, które skierował święty Paweł do Koryntian, wyprowadza wniosek, ze obie natury łączy podmiot jednego i tego samego Chrystusa: idem Deus, idem homo, per divinitatem Deus, per susceptionem carnis homo. Użycie zaimka wskazującego: idem nie pozostawia cienia wątpliwości, że chodzi tutaj o jedną i tę samą osobę. Dodatkowo podkreśla tę jedność dalsza konstrukcja słowna: indiscrete et „dominus maiestatis” dicatur esse, qui passus est, et filius hominis, sicut scriptum est, qui descendit de caelo. Zastosowany tutaj przysłówek: indiscrete ${ }^{57}$, przy uprzednim ostrym rozróżnieniu mię-

55 Tamże V 8, 106, SAEMO 15, 384-386, Bogaszewicz s. 186.

56 Tamże II 7, 58, SAEMO 15, 154, Bogaszewicz s. 59. Na ten fragment powołuje się Sobór w Chalcedonie (451), por. ACO II 1, 1, s. 22, 8-17.

57 Por. Słownik lacińsko-polski, red. M. Plezia, III, Warszawa 1969, 117: „bez różnicy”, „zarówno”, ,jednako”. Autor polskiego wydania thumaczy to słowo jako „,jednocześnie”, por. Bogaszewicz s. 59. 
dzy dwoma naturami, pozwala wnioskować, że zdaniem Autora niemożliwością jest jakiekolwiek myślenie o dwóch niezależnych podmiotach. Owszem, pewna dwoistość może być widoczna w dziełach Chrystusa, które są boskie i ludzkie, ale nie pod względem różnicy osób, bo jest tylko jedna osoba: Syna Bożego $^{58}$.

Motyw „ukrzyżowanego Pana chwały” jest przywołany jeszcze w innym miejscu przez Biskupa Mediolanu, w kontekście dowodzenia, iż Duch Święty również jest Panem chwały. Kluczowym dla nas jest stwierdzenie, które pada przy tej okazji. Otóż Ambroży kategorycznie stwierdza, że „nie ma innego Chrystusa, lecz jeden jest i przed wiekami z Ojca, jako Syn Boży zrodzony, i w czasie jako człowiek zrodzony przez przybranie ciała"59. Na zasadzie antytezy: ante saecula ut Dei filius - in saeculo ut homo, została ukazana w sposób zdecydowany różnica natur. Mimo jednak tej przepaści bytowej nie ulega wątpliwości, że non alter Christus, sed unus est ${ }^{60}$.

Bardzo ważne stwierdzenie pada również w innym miejscu traktatu De fide:

„Czym innym jest zatem Syn Boży z tytułu Bożej substancji, a czym innym z tytułu przyjętego człowieczeństwa. Albowiem z powodu swego Bożego narodzenia równy jest Ojcu, natomiast $\mathrm{z}$ powodu przyjętego ciała jest Jego sługą, bo "przyjął postać sługi» (Flp 2,6). A jednak jeden i ten sam jest Syn"61.

Ambroży rozróżnia więc wyraźnie w Jezusie Chrystusie dwoistość natur ${ }^{62}$. Będąc uczestnikiem natury Boskiej równy jest Ojcu (Deo Patri „aequalis est” filius), co jest równoznaczne z jego boskością. Równocześnie jednak jest On zależny od Boga Ojca przez przyjęcie ziemskiego bytowania. Dlatego można powiedzieć za świętym Pawłem, że Syn Boży stał się sługą w ludzkiej naturze, ponieważ ,przyjął postać sługi”. Mimo że, jak zaznacza Ambroży, są to sprawy przerastające możliwości ludzkiego umysłu, to jednak jedność Syna Bożego jest niepodważalna (unus tamen atque idem est filius). Cytowany wyżej tekst jest interesujący dla omawianej problematyki jeszcze z innego powodu. Otóż zawarte są w nim implicite pewne przesłanki, które wskazują, że Ambroży zastanawiał się nad tym, co konstytuuje wewnętrzną jedność Jezusa Chrystusa. Wydaje się, że tym czynnikiem jest osoba Syna Bożego, bo to ją czyni nasz autor podmiotem bóstwa i człowieczeństwa. Chociaż należy także przyznać, że Ambroży w dziele De fide użył zwrotu: ex persona hominis Patrem dixit maio-

${ }^{58}$ Por. A. Grillmeier, Jesus der Christus im Glauben der Kirche, Bd. I: Von der Apostolischen Zeit bis zum Konzil von Chalcedon (451), Freiburg - Basel - Wien 1979, 594; także H.M. Diepen, L', assumptus homo” patristique, , Revue Thomiste” 63 (1963) 369.

${ }^{59}$ De Spiritu Sancto III 22, 168, SAEMO 16, 354.

60 Tamze.

61 De fide V 8, 107, SAEMO 15, 386, Bogaszewicz s. 186.

${ }^{62}$ Por. tamże: ,aliud igitur est secundum divinam substantiam, aliud secundum susceptionem carnis filium nominari”. 
rem $^{63}$. Nie wydaje się jednak, w kontekście innych fragmentów, które tutaj zostały przytoczone, żeby Biskup Mediolanu w duchu nestoriańskim uznawał istnienie osoby ludzkiej w Jezusie Chrystusie ${ }^{64}$, ale raczej należy stwierdzić, że stanowisko Ambrożego jest całkowicie zgodne z nauką Soborów: Efeskiego $(431)^{65}$ i Chalcedońskiego $(451)^{66}$, które zresztą kilkakrotnie nawiązują do nauczania Biskupa mediolańskiego ${ }^{67}$. Sobór Efeski czyni to m.in. w stosunku do tego fragmentu:

„Powinniśmy również potępić tych, którzy głoszą, że Pan Jezus przyszedł na ziemię jako zjawa, bo oni konsekwentnie rozwijając swoją myśl twierdzą, że nie istniał jeden i ten sam Syn Boży, lecz że kto inny narodził się z Ojca, a kto inny z Dziewicy. A przecież ewangelista mówi: «Słowo ciałem się stało» dla potwierdzenia naszej wiary w istnienie jednego Pana Jezusa, a nie dwóch" ${ }^{\text {"68. }}$.

Niniejsza wypowiedź skierowana jest przeciw doketyzmowi, a więc herezji, która odmawiała Jezusowi Chrystusowi prawdziwości ciała ludzkiego, a przypisywała mu jedynie pozorne ciało. Była to konsekwencja przyjmowania platońskich poglądów o „poniżającej” funkcji ciała ${ }^{69}$, jakoby Bóg nie mógł przyjąć ciała, bo jako ,inteligencja wyższa” nie mógł łączyć się z materią. Rezultatem takich poglądów jest, zdaniem Ambrożego, całkowite rozgraniczanie Syna Bożego zrodzonego z Ojca i narodzonego z Dziewicy ${ }^{70}$, co jest nie do przyjęcia w świetle nauki św. Jana Apostoła, który stwierdza, że „Słowo ciałem się stało”

63 Tamże II 8, 61, SAEMO 15, 154.

${ }^{64}$ Dlatego I. Bieda proponuje, żeby wyrażenie ex persona thumaczyć: ,,jako człowiek”, por. Chrystologia, SWP 441; por. także B. Altaner - A. Stuiber, Patrologia. Życie, pisma i nauka Ojców Kościoła, tłum. P. Pachciarek, Warszawa 1990, 511. Warto tutaj zaznaczyć, że J. Liebert wprost stwierdza: ,in ihm [Christus - przyp J.F.] gibt es Verschiedenheit der Natur oder der Substanz, 'aliud' und 'aliud', nicht aber 'alter' und 'alter', d.h. Verschiedenheit der Person", por. Christologie: von der Apostolischen Zeit bis zum Konzil Chalkedon (451), HDG III 1a (Freiburg - Basel - Wien 1965), 96.

${ }^{65}$ Por. Denzinger 250-268; BF VI 3-5.

${ }^{66}$ Por. Denzinger 301, BF VI 8.

67 Sobór Efeski (431) powołuje się na fragmenty De incarnationis 47-54, por. ACO I 4, 2 , s. $121,1-122,12$. Natomiast Sobór Chalcedoński (451) cytuje również traktat De incarnationis $49 \mathrm{i}$ 52, por. ACO II 1, 1, s. 22, 25 i 23, 1, oraz traktat De fide II 7, 58 i II 9, 77, por. ACO II 1, 1, s. 22 , 8-17. Więcej na temat wpływu św. Ambrożego na teologię Wschodu zob. m.in. A. Petrusi, Le antiche traduzioni greche delle opere di $S$. Ambrogio e l' Expositio fidei" a lui falsamente attributa, „Aevum” 18 (1944) 184-207; C. Passini, La figura di Ambrogio nell' Oriente bizantino, SC 109 (1981) 417-459; tenże, Le fonti greche su sant'Ambrogio, = SAEMO 24/1: Sussidi, Milano-Roma 1990; J. Grzywaczewski, Recepcja św. Ambrożego w Kościele Wschodnim, VoxP 18 (1998) t. 34-35, 227-256.

${ }^{68}$ De incarnationis 6, 47, SAEMO 16, 408, POK 26, 120; por. ACO I 4, 2, s. 121, 1.

${ }^{69}$ Por. G.L. Müller, Chrystologia - nauka o Jezusie Chrystusie, w: Podręcznik teologii dogmatycznej, t. 5, red. W. Beinert, tłum. W. Szymona, Kraków 1998, 307.

${ }^{70}$ Por. De incarnationis 6, 47, SAEMO 16, 408: ,non unum eundemque filium Dei dicunt, sed alium esse, qui ex Deo patre natus sit, alium, qui sit generatus ex virgine". 
(J 1, 14). Mediolańczyk odwołuje się więc do tradycji pierwotnego Kościoła. Już wtedy prowadzona była polemika z doketami i tymi wszystkimi, którzy negowali realność ciała Jezusa Chrystusa (por. też 1 J 4, 2-3; 2 J 7). Święty Ambroży, zgodnie $\mathrm{z}$ tradycją chrześcijańską, potwierdza więc prawdziwość i rzeczywistość ciała Jezusa oraz Jego boskie prerogatywy, przypominając implicite, że osoba Syna Bożego jest podmiotem łączącym dwie natury.

W podobnym tonie utrzymana jest kolejna wypowiedź św. Ambrożego, na którą powoła się później Sobór Konstantynopolitański II $(553)^{71}$ :

„Przeciwko wszystkim skierowane jest jednak to ogólne wyznanie, że «Chrystus jest Synem Boga» (por. Mt 16,16), i to jako odwieczny z Ojca, a jako narodzony z Dziewicy. Prorok Dawid opisuje Go jako olbrzyma dlatego, że stał się jednym o dwóch bliźniaczo złączonych naturach, że posiada Bóstwo i ciało. «Jako oblubieniec wychodząc ze swej komnaty ucieszył się jak olbrzym, co ma przebiec drogę» (Ps 18, 6). Jako Słowo jest oblubieńcem duszy. Jest olbrzymem ziemi, bo przebiegając przez obowiązki naszego życia, chociaż zawsze był odwiecznym Bogiem, przyjął tajemnicę Wcielenia, nie podzielony, lecz jeden, gdyż jest jednością dwóch i jeden z obydwu, to jest w Bóstwie i w ciele. Nie jest bowiem inny z Ojca a inny z Dziewicy, ale ten sam inaczej z Ojca, a inaczej z Dziewicy" ${ }^{\text {"72. }}$.

Jest to klasyczny tekst, w którym ujęte są najważniejsze elementy zjednoczenia osobowego, które dokonało się w Jezusie Chrystusie. Pada więc stwierdzenie, że w Chrystusie - Synu Bożym znajduje się jedyny podmiot boskości i człowieczeństwa w taki sposób, ze jest on elementem konstytutywnym dla dwóch bliźniaczo złączonych natur ${ }^{73}$. To złączenie natur, określone mianem „bliźniacze", sugeruje, że nie ma w nich żadnych ubytków, powstałych na skutek zjednoczenia. Obie są pod każdym względem doskonałe tak, że mogłoby wydawać się iż są dwie osoby. Jednak Chrystus nie jest podzielony, lecz jeden (non divisus, sed unus), do tego stopnia, że można mówić o Nim: ,jedność dwóch" (utrumque unus) i ,jeden w obydwu" (unus in utroque). I na koniec przytoczonego fragmentu pada wspaniała konkluzja zbudowana na grze słów: Non enim alter ex Patre et alter ex virgine, sed idem aliter ex Patre, aliter ex virgine. Kluczową rolę pełnią tu więc określenia: alter i aliter, które znakomicie oddają jedność osoby Jezusa Chrystusa, przy jednoczesnym podkreśleniu różnicy dwóch natur: Boskiej i ludzkiej.

Ta jedność zostanie wyeksponowana jeszcze kilka razy przez naszego autora. Wydaje się, że najbardziej dobitnie zostało to m.in. wyrażone w poniższym zdaniu: „Ten sam Syn Boży przemawia w naturze ludzkiej i Boskiej, gdyż posiada obie natury" ${ }^{74}$. $\mathrm{Z}$ jednej strony jest to argument za podmiotową jed-

71 Por. ACO IV 2, s. 82, 12-17.

72 De incarnationis 5, 35, SAEMO 16, 396-398, POK 26, 116.

73 Por. tamze: ,biformis geminaeque naturae unus sit, consors divinitatis et corporis”.

74 De fide II 9, 77, SAEMO 15, 162-164, Bogaszewicz s. 64. Ten fragment cytuje Sobór Chalcedoński (451), por. ACO II 1, 1, s. 22, 17. 
nością Syna Bożego w dwóch naturach, ale z drugiej istnieje niebezpieczeństwo zmieszania elementów, właściwych poszczególnym naturom. Dlatego Ambroży dołącza klauzulę: „I chociaż Ten sam przemawia, to nie zawsze przemawia w ten sam sposób. Trzeba w Nim baczyć już to na chwałę Bożą, już to na ludzką słabość. Jako Bóg mówi rzeczy Boże, bo jest Słowem, jako człowiek - rzeczy ludzkie, gdyż przemawia w naszej naturze" ${ }^{, 75}$.

Takie lub podobne sformułowania bardzo często występują w nauczaniu naszego Autora. Łatwo można wysnuć stąd wniosek, że dla Ambrożego znajomość tej problematyki to sprawa najwyższej rangi. Nie można postrzegać Jezusa Chrystusa tylko oczami zmysłowymi, bo On pragnie, aby wierzyć, ,iż ten sam Jezus Chrystus jest Synem Bożym i człowiekiem" ${ }^{76}$. Jednak rozróżnienie między obydwoma naturami jest ostro podtrzymywane: ,Jezus Chrystus zaś ten sam jest wczoraj i dziś, i na wieki: «wczoraj» z powodu swego wiekuistego istnienia, «dziś» z powodu przyjętego ciała"77. Należy wiec stwierdzić, że dwie natury w Chrystusie zachowują odnośne właściwości i jednoczą się poprzez wcielenie w jednej osobie, $\mathrm{z}$ czego wynika doskonałość Jezusa zarówno w jednej, jak i w drugiej naturze.

W ten sposób staraliśmy się prześledzić myśl św. Ambrożego zawartą w pismach dogmatycznych, dotyczącą niektórych aspektów wcielenia. Przedstawione wyżej wypowiedzi pozwalają wnioskować, że nasz Autor dostrzega nadzwyczajność tego wydarzenia. Po pierwsze podkreśla z całą mocą, że wcielił się tylko i wyłącznie Syn Boży, a więc druga Osoba Trójcy Świętej, i konsekwentnie twierdzi dalej, że to On cierpiał na krzyżu, ale w swej ludzkiej naturze, ponieważ jako Bóg nie podlegał cierpieniu. Po wtóre dostrzega, ze Jezus Chrystus jest zarazem Synem Boga Ojca i synem Dziewicy Maryi z rodu Dawida. Dlatego można powiedzieć, że ,przez swoje niebiańskie narodzenie Syn Boży urodził się «bez matki», ponieważ się zrodził z samego Boga Ojca, a znowu - «bez ojca», gdyż urodził się z Dziewicy" "78. Pierwsza relacja wskazuje na prawdziwość bóstwa Jezusa Chrystusa, a druga na prawdziwość człowieczeństwa. Te dwie rzeczywistości, zdaniem Ambrożego, zawsze idą ze sobą w parze i nie można ich rozdzielać. Jednym z najważniejszych dokonań Biskupa Mediolanu jest stwierdzenie podmiotowej jedności Jezusa Chrystusa, Bogaczłowieka, przy równoczesnym podkreśleniu różnicy między naturą boską i ludzką, przez co stał się on jednym z prekursorów nauczania Soboru Efeskiego (431) i Chalcedońskiego (451).

\footnotetext{
75 Tamże II 9, 77, SAEMO 15, 162-164, Bogaszewicz s. 64.

76 Tamze V 10, 121, SAEMO 15, 292, Bogaszewicz s. 190-191.

77 Tamże V 1, 25, SAEMO 15, 344, Bogaszewicz s. 164.

78 De sacramentis IV 3, 12, SAEMO 17, 90-92, POK 26, 74.
} 


\section{DAS PHÄNOMEN DER MENSCHWERDUNG GOTTES IN DOGMATISCHEN SCHRIFTEN DES HL. AMBROSIUS VON MAILAND}

\section{(Zusammenfassung)}

Der Artikel stellt einige Aspekte der dogmatischen Lehren des hl. Ambrosius von der Menschwerdung dar. Vor allem legt Bischof von Mailand großes Gewicht auf die Tatsache der Menschwerdung des Sohnes Gottes. Nur zweite Person der Trinität hat den Leib angenommen - kein Vater, sondern Sohn Gottes. Hl. Ambrosius betont auch, dass Christus wahrer eingeborener Gottes Sohn und wahrer Sohn der Jungfrau Maria ist. Er spricht also von wahrer Gottheit und von wahre Menschheit Christi. Die Lehre von der personalen Einheit Christi mit der scharfen Trennung zwischen seiner Gottheit und Menschheit gehört zu seinen wichtigsten Erreichungen. Hl. Ambrosius ist darum einer von den Vorläufern der Inkarnationslehre des Konzils von Ephesus (431) und Chalcedon (451). 